\title{
An exploration of addiction in adults experiencing early-life stress: a metasynthesis ${ }^{1}$
}

\author{
Carla Araujo Bastos Teixeira² \\ Gerri Lasiuk ${ }^{3}$ \\ Sylvia Barton ${ }^{4}$ \\ Maria Neyrian de Fatima Fernandes ${ }^{5}$ \\ Edilaine Cristina da Silva Gherardi-Donato ${ }^{6}$
}

\begin{abstract}
Objective: to review and synthesize qualitative research on the links between early-life stress and addiction behaviours in adulthood. Method: metasynthesis to review qualitative research findings based on procedures that outline how to identify themes or constructs across studies in a specific area. Comprehensive searches of multiple electronic databases were performed. The initial search yielded 1050 articles and the titles and abstracts were screened for inclusion based on predetermined criteria. Thirty-eight full text, peer-reviewed articles were retrieved and assessed by three independent reviewers. Twelve articles were eligible for full review and appraised using the Critical Appraisal Skills Programme (CASP) tools. Results: the findings revealed that clear associations exist between early-life stress and addictive behaviours in adulthood, such as between trauma in childhood, violence, and addictive behaviours. A common theme in the findings indicates that participants turn to addictive substances as a way of strategically coping with stressful childhood experiences, regardless of the harmful side effects or detrimental social outcomes. Conclusion: it can be inferred that addiction may be viewed as a way to deal with adversity in childhood and that there is an interrelationship between addiction, domestic violence and crime.
\end{abstract}

Descriptors: Child Abuse; Behavior Addictive; Adult Survivors of Child Adverse Events.

\footnotetext{
1 Supported by Conselho Nacional de Desenvolvimento Científico e Tecnológico (CNPq), Brazil, process \#206234/2014-7.

2 Doctoral student, Escola de Enfermagem de Ribeirão Preto, Universidade de São Paulo, PAHO/WHO Collaborating Centre for Nursing Research Development, Ribeirão Preto, SP, Brasil. Bolsista do Conselho Nacional de Desenvolvimento Científico e Tecnológico (CNPq), Brasil.

${ }^{3} \mathrm{PhD}$, Associate Professor, College of Nursing, University of Saskatchewan, Edmonton, Alberta, Canada.

${ }^{4} \mathrm{PhD}$, Associate Professor, Faculty of Nursing, Edmonton Clinic Health Academy, Edmonton, Alberta, Canada.

${ }^{5}$ Doctoral student, Escola de Enfermagem de Ribeirão Preto, Universidade de São Paulo, PAHO/WHO Collaborating Centre for Nursing Research Development, Ribeirão Preto, SP, Brasil. Assistant Professor, Universidade Federal do Maranhão, Imperatriz, MA, Brazil.

${ }^{6}$ PhD, Associate Professor, Escola de Enfermagem de Ribeirão Preto, Universidade de São Paulo, PAHO/WHO Collaborating Centre for Nursing Research Development, Ribeirão Preto, SP, Brazil.
}

\section{How to cite this article}

Teixeira CAB, Lasiuk G, Barton S, Fernandes MNF, Gherardi-Donato ECS. An exploration of addiction in adults experiencing early-life stress: a metasynthesis. Rev. Latino-Am. Enfermagem. 2017;25:e2939. [Access Available in: DOI: http://dx.doi.org/1518-8345.2026.2939. 


\section{Introduction}

Healthy child development is built on a foundation of supportive and responsive relationships with caregivers $^{(1)}$. The stress associated with the disruption or absence of these relationships when brain structures are developing, has long-term and negative effects on emotional, behavioural, social, and physical health and well-being throughout an individual's life ${ }^{(2-3)}$.

Child maltreatment is an umbrella term for all forms of physical/emotional/sexual abuse, neglect, and exploitation that occurs before 18 years of age and is associated with actual or potential harm to the child's health, survival, development, or dignity(4). The following four categories of child maltreatment are typically recognized: neglect, physical abuse, psychological or emotional abuse, and sexual abuse ${ }^{(2,5-7)}$. Child maltreatment is a serious public health problem around the globe $^{(8)}$ and has implications for childhood mortality and morbidity and lifelong mental health, substance misuse, high-risk sexual behaviour, obesity, and criminal behaviour(9-10).

Rates of child maltreatment are challenging to estimate because of differences in definitions, sampling strategy, and method of data collection, as well as methodology. What is more disconcerting is that $50 \%-$ $80 \%$ of cases go unreported ${ }^{(8,10)}$. A meta-analysis of 13 independent samples $(n=59,406)$ reported that $16.3 \%$ of children around the world are victims of physical neglect and a further $18.4 \%$ have experienced emotional neglect(11). As many as $25 \%$ of adults report having been physically abused as children ${ }^{(4)}$. Another meta-analysis ${ }^{(12)}$ (331 independent samples and $\mathrm{n}=9,911,748$ participants) estimated the international prevalence of child sexual abuse to be $12.7 \%$. The same study found that rates of sexual abuse of females and males to be $18 \%$ and $7.6 \%$ respectively.

Studies suggest that the early-life associated with child maltreatment also has deleterious consequences in adulthood(13). Adults who have experienced some form of early-life stress may present with a wide range of physical health problems, mood, anxiety, and personality disorders, and/or misuse of alcohol and other licit and illicit substances(6,14-15). The effects of child maltreatment serve as markers of endophenotypic susceptibility to diseases through the hypothalamicpituitary-adrenal (HPA) axis dysfunction(16). Early-life stress can result in permanent changes in HPA axis function, morphological changes in the brain, and gene expression changes, all of which are implicated in the abuse of psychoactive substances(17). In other words, stress in early-life may act as a catalyst for substance misuse behaviours. Stressful experiences in childhood, including physical and psychological abuses, are thought to establish a relationship with the binomial risk-resilience for the development of alcohol and drug dependence.

Although the relationship between early-life stress and the misuse of psychoactive substances has been substantiated in the basic science literature, an appreciation of the psychosocial processes involved goes beyond statistical causality. The meaning of life events to individuals and the links to subsequent behaviours are difficult to illustrate through quantitative research studies. A metasynthesis of qualitative research on addiction in adults who have experienced early-life stress will provide additional knowledge and a deeper understanding of the psychosocial and intrapersonal dynamics of addictive behaviours. It addresses the following question: What does the qualitative research literature reveal about the experience of early childhood stress and the presence of addictive behaviour in adulthood?

\section{Aim}

The purpose of this metasynthesis was to explore studies on early-life stress and links to addiction in adulthood. The specific procedural steps were to search, appraise, classify, and synthesize the findings of qualitative research in order to describe the existence of addiction among adults with links to the experience of early-life stress.

\section{Method}

\section{Design}

Metasynthesis is an approach to reviewing qualitative research findings based on procedures that outline how to identify themes or constructs across studies in a specific area. This metasynthesis involved a comprehensive search, appraisal of the results of qualitative studies, study classification, and synthesis of the results ${ }^{(18)}$. These procedures were chosen because it allows the researcher to build a set of relevant assumptions, aggregating the results of several primary studies; and to discover the "state of the art" whereby the contributions of 
combining qualitative research findings enhances their contribution to the development of new knowledge and future knowledge applications ${ }^{(19-22)}$. The goal of a metasynthesis is to broaden and deepen the understanding of a particular phenomenon ${ }^{(23)}$.

\section{Search method}

Comprehensive searches of Medline, PsyciNFO, CINAHL, Web of Science and SCOPUS databases were performed. Primary search terms included subject headings and text words associated with key concepts related to the review question. The terms were divided into three broad categories: 1) child abuse ("trauma" "Battered Child Syndrome", "adverse experience", "aggression", "forced sex", "child abuse", "victim", early life experience"); 2) addiction/ misuse of substances ("substance-related disorders", "addiction", "substance misuse", "overconsumption"); and 3) qualitative studies ("qualitative research", "anthropology", "ethnography", "hermeneutic", "phenomenology", "lived experience", "grounded theory"). The search terms were refined during the search process and various combinations of subject headings and keywords were used depending on the database and the controlled vocabularies available; no limits were placed on publication dates. The searches were conducted in July and August 2015. The peer-reviewed articles were retrieved and assessed by three independent reviewers. In case of disagreement in any of the phases, the articles were re-read and discussed until the disagreement was resolved. EndNote ${ }^{\circledR}$ was used to organize and manage references. Inclusion/exclusion criteria were developed using a modified PICOS framework(24): Population: Adults (18 years and older) who self-report early-life stress. Phenomenon of Interest: Meaning/subjective description of the experience of addiction. Context: Individuals who report having early-life stress and who have experienced addiction in adulthood. Outcome: Subjective descriptions of addiction. Study design: Metasynthesis of findings of primary qualitative research studies.

\section{Quality Appraisal}

Quality appraisal of studies in the review was performed using Critical Appraisal Skills Programme (CASP) tools. Recommended by the Joanna Briggs Institute, the CASP Qualitative Research Checklist tool offers a standardized approach for evaluating the rigour of qualitative studies ${ }^{(25)}$. The Checklist consists of 10 questions: two for the selection of studies and eight for the design of research, data collection and analysis, ethics, reflexivity and implications of qualitative research(26). According to the authors, the first three questions are fundamental. If for any of them the answer is "no," the article has to be excluded; thus the article is considered outside the required methodological standards criteria and is left out.

\section{Data Extraction}

The instrument elected to extract the data was

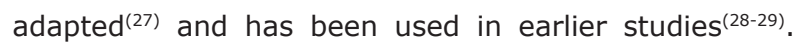
The adapted items used were author, title, keywords, journal, database, country, year, aim, methods, findings, reference and additional information. The reviewers independently reviewed the extracted data using this instrument, which consists of five domains: identification of the study, setting of study, journal, methodological characteristics of the study, and quality appraisal.

\section{Data analysis}

Employing a method(30) that the data were analyzed in the following way: (i) initial reduction/ classification of the data into systematic categories; (ii) clustering of primary source data through an interactive contrasting, comparing process; and (iii) drawing conclusions about each sub-group analysis and synthesizing relevant elements into an integrated summary ${ }^{(31)}$.

\section{Validity}

The validity for this meta-synthesis was grounded in a comprehensive search for literature, group discussion on search terms and inclusion criteria(18), group assessment of appraisal of CASP, and agreement about decisions. The authors also discussed findings of the studies and themes until a consensus was reached.

\section{Results}

The initial search generated 1050 records; 22 duplicates were removed. Preliminary screening of titles resulted in the elimination of an additional 929 records. The abstracts of the remaining 126 records were screened and 88 of these were discarded. The full texts of 38 records were reviewed and the 12 articles that met all inclusion criteria were retained for full review (See Figures 1 and 2). 


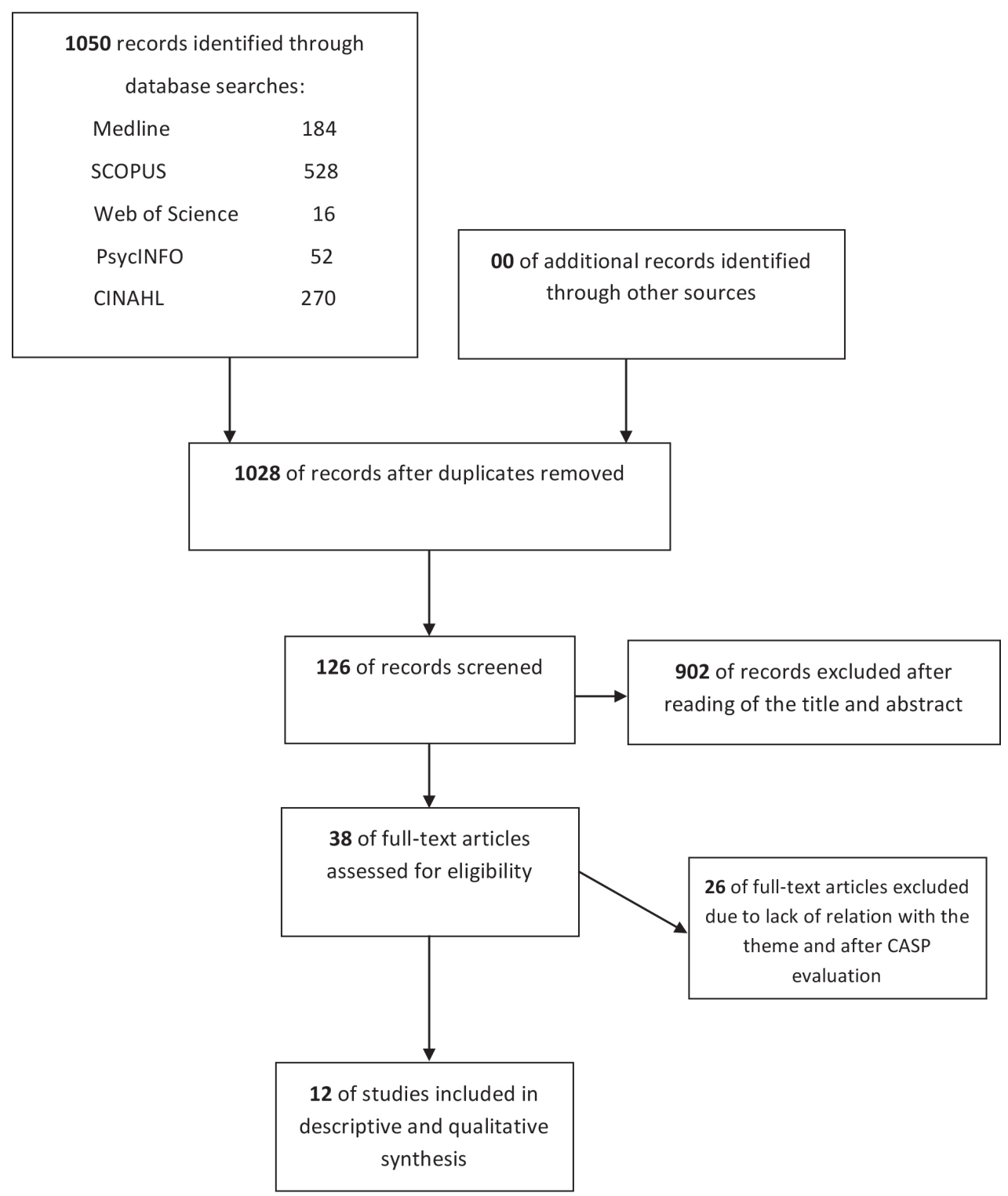

Figure 1 - Flow chart of study selection for meta-synthesis.

\begin{tabular}{|c|c|c|c|}
\hline Authors/Country & $\begin{array}{l}\text { Study Design/ Theoretical } \\
\text { approach / Frameworks }\end{array}$ & Participants & Findings \\
\hline $\begin{array}{l}\text { Bittar \& Nakano (2011) } \\
\text { Brazil }\end{array}$ & Generic qualitative approach & $\begin{array}{l}10 \text { women, mothers living in } \\
\text { the context of alcohol, drugs } \\
\text { and violence. }\end{array}$ & $\begin{array}{l}\text { The family and social context in which the women } \\
\text { lived during their process of socialization in their } \\
\text { original family home unites factors that contribute } \\
\text { to manifest acts of violence against their children. } \\
\text { Aggressive mothers have a common profile like } \\
\text { aggression and loss in childhood, alcohol abuse } \\
\text { situations in adulthood. }\end{array}$ \\
\hline $\begin{array}{l}\text { Bittar, et al. (2012) } \\
\text { Brazil }\end{array}$ & Generic qualitative approach & $\begin{array}{l}10 \text { women, mothers living in } \\
\text { the context of alcohol, drugs } \\
\text { and violence. }\end{array}$ & $\begin{array}{l}\text { The abuse victims are more prone to learning } \\
\text { disabilities, behaviour disorders, self-defeating } \\
\text { behaviours and low self-esteem. }\end{array}$ \\
\hline $\begin{array}{l}\text { Bowles, DeHart \& } \\
\text { Webb (2012) } \\
\text { USA }\end{array}$ & Grounded Theory & $\begin{array}{l}60 \text { women incarcerated in a } \\
\text { maximum security facility. }\end{array}$ & $\begin{array}{l}\text { Substance use may arise from a need to cope with } \\
\text { child victimization and adversity, and those factors } \\
\text { such as poor parental supervision may contribute } \\
\text { to substance use. After onset of drug use, many } \\
\text { women may turn to further criminal activity to support } \\
\text { their habits. }\end{array}$ \\
\hline $\begin{array}{l}\text { Coyer (2003) } \\
\text { USA }\end{array}$ & $\begin{array}{l}\text { Bronfenbrenner's ecological } \\
\text { framework }\end{array}$ & $\begin{array}{l}11 \text { women recovering from } \\
\text { cocaine addiction. }\end{array}$ & $\begin{array}{l}\text { Lack of structure in child care, abandonment of } \\
\text { children, impatience/anger, repeating dysfunctional } \\
\text { parent practices from their family of origin are factors } \\
\text { presents in those women. }\end{array}$ \\
\hline $\begin{array}{l}\text { Davis (1997) } \\
\text { USA }\end{array}$ & Phenomenology & 15 African American women. & $\begin{array}{l}\text { The painful past experiences of African American } \\
\text { woman may have led to subsequent substance } \\
\text { abuse problems. The lack of needed love and } \\
\text { attention during vulnerable childhood years was } \\
\text { potentially devastating. }\end{array}$ \\
\hline
\end{tabular}




\begin{tabular}{|c|c|c|c|}
\hline Authors/Country & $\begin{array}{l}\text { Study Design/ Theoretical } \\
\text { approach / Frameworks }\end{array}$ & Participants & Findings \\
\hline $\begin{array}{l}\text { Davison (2007) } \\
\text { UK }\end{array}$ & Feminist standpoint theory & $\begin{array}{l}21 \text { women who experienced } \\
\text { drinking problems from } \\
\text { community populations. }\end{array}$ & $\begin{array}{l}\text { Heavy drinking served to briefly mediate the } \\
\text { dilemmas of oppressive experience by blunting } \\
\text { conflicts between dependence and interdependence, } \\
\text { personal power and powerlessness. }\end{array}$ \\
\hline $\begin{array}{l}\text { Dunlap, et al. (2009) } \\
\text { USA }\end{array}$ & Ethnography & $\begin{array}{l}178 \text { participants who became } \\
\text { crack users in } 72 \text { families } \\
\text { from inner-city New York }\end{array}$ & $\begin{array}{l}\text { Such physical punishment also socialized and } \\
\text { prepared children for the violence that would likely } \\
\text { occur during their childhood. This analysis highlights } \\
\text { how reducing substance abuse in the inner city may } \\
\text { require a much more comprehensive effort than a } \\
\text { focus on reducing physical abuse in childhood. }\end{array}$ \\
\hline $\begin{array}{l}\text { Hänninen \& } \\
\text { Koski-Jännes, (1999) } \\
\text { Finland }\end{array}$ & Narrative psychology & $\begin{array}{l}51 \text { ( } 22 \text { men and } 23 \text { women) } \\
\text { people who had been able to } \\
\text { quit their addiction to alcohol, } \\
\text { multiple drugs, binge eating, } \\
\text { smoking, sex and gambling. }\end{array}$ & $\begin{array}{l}\text { As there are several ways out of addictive } \\
\text { behaviours there are also several ways to construe } \\
\text { the change. People who try to quit addictive } \\
\text { behaviours could be encouraged to make full use of } \\
\text { the cultural stock of stories in creating an account } \\
\text { that fits their own experience of defeating their } \\
\text { particular addiction. }\end{array}$ \\
\hline $\begin{array}{l}\text { Johnson \& Young (2002) } \\
\text { USA }\end{array}$ & Relational theory & $\begin{array}{l}5 \text { women with drug } \\
\text { history and had } 3 \text { or more } \\
\text { incarcerations. }\end{array}$ & $\begin{array}{l}\text { The effects of childhood sexual abuse continue to } \\
\text { impact women into adulthood. Alcohol and drugs } \\
\text { were also used as a way to endure the trauma } \\
\text { associated with early sexual abuse. }\end{array}$ \\
\hline $\begin{array}{l}\text { Mirlashari, et al. (2012) } \\
\text { Iran }\end{array}$ & Grounded theory & $\begin{array}{l}15 \text { drug users and } 4 \text { family } \\
\text { members (men and women) } \\
\text { who were recruited from } \\
\text { treatment centers. }\end{array}$ & $\begin{array}{l}\text { There appears to be a significant disconnect } \\
\text { between individuals who experienced traumatic } \\
\text { events during childhood and their families. An } \\
\text { obedience instilling parenting style and parents' } \\
\text { knowledge and attitude toward drug using and } \\
\text { prevention were also identified as important } \\
\text { determinants of substance use. }\end{array}$ \\
\hline $\begin{array}{l}\text { O'Brien, Brecht \& } \\
\text { Casey (2008) } \\
\text { USA }\end{array}$ & Ethnography & 13 methamphetamine users. & $\begin{array}{l}\text { Drug initiation emerging from abuse during childhood } \\
\text { and parental drug abuse. Respondents entered } \\
\text { drug-using peer groups that paradoxically offer both } \\
\text { protection from and vulnerability to violence and } \\
\text { other problems. Consequences of MA abuse include } \\
\text { economic instability and concern with only the } \\
\text { acquisition and use of MA. }\end{array}$ \\
\hline $\begin{array}{l}\text { Valtonen, et al. } \\
\text { (2009) } \\
\text { Trinidad and Tobago }\end{array}$ & QCA-Ragin's Method & $\begin{array}{l}15 \text { participants from } \\
\text { Barbados target group and } \\
33 \text { participants from Trinidad } \\
\text { target group. }\end{array}$ & $\begin{array}{l}\text { Nearly half of the Trinidad group and two-thirds of } \\
\text { the Barbados group reported experience of rejection } \\
\text { or abandonment in childhood. A profile of stressful } \\
\text { or traumatic experiences was compiled for each } \\
\text { participant, from which it was possible to identify } \\
\text { co-occurring pairs of stressors, which suggest inter- } \\
\text { relationships between the phenomena. }\end{array}$ \\
\hline
\end{tabular}

Figure 2 - Studies included in the meta-synthesis

\section{Sources of Early-Life Stress}

Participants in the studies in this review reported a variety of sources of early-life stress and no single subtype stood out. Participants described early-life stress associated with physical, emotional/psychological, and sexual abuse; physical neglect; and emotional neglect. Others reported stress related to parental loss, divorce, and abandonment. In all studies, early life stress was self-reported. There was no use of instruments to measure child abuse.

The findings of this metasynthesis support the claim that for many people, adult addiction is closely related to early-life stress. The major theme across all 12 studies in this review is that use of psychoactive substances, gambling, and sex served as ways of coping with stressful circumstances experienced at an early age. In some studies ${ }^{(32-36)}$ participants report engaging in addictive behaviours in childhood which continued into adulthood. Regardless of when the addiction behaviour began, the common factor among participants is that addiction in adulthood is a way of coping with the effects of early-life stress.

In eight of the twelve studies ${ }^{(32-34,37-41)}$, alcohol was identified as the drug of abuse. Five studies ${ }^{(32-35,40)}$ addressed poly-substance use; two ${ }^{(35-36)}$ addressed the use of methamphetamine; two ${ }^{(33,42)}$ focused on crack use; three articles $^{(32,41,43)}$ focused on cocaine use; and one study ${ }^{(35)}$ addressed opium and heroin use. An $\operatorname{article}^{(40)}$ focused on process addiction, including sex addiction, smoking, binge eating, alcohol misuse and gambling, and the misuse of chemical substances. The others highlighted adverse situations experienced in childhood as an important factor in the misuse of chemical substances.

A notable finding is the existence of relationships between addiction, crime, and domestic violence. Nine of the twelve studies ${ }^{(32-33,35-39,41,43)}$ identify domestic violence as a fertile setting for child abuse and substance abuse. Two studies ${ }^{(32,34)}$ describe crime as the final point in life trajectories marked by childhood maltreatment and substance misuse. Two studies ${ }^{(32,34)}$ focused specifically 
on the experiences of incarcerated persons and the abuse of substances

\section{Discussion}

This metasynthesis provides insight into the experience of addictive behaviour in adulthood in relation to the occurrence of early life stress. The studies included in this review reveal that addiction in adult life is a way of coping with the trauma of stressful experiences in childhood. Another important finding was the relationship between trauma in childhood, violence, and addictive behaviours.

\section{Addiction as a Coping Strategy}

Coping, defined as a set of cognitive-behavioural actions developed by the individual throughout their life course experiences, develops as a result of many stressors, in order to change adverse aspects in the environment and regulate potential threats arising from these ${ }^{(44)}$. Coping strategies are used to deal with demands or stressors (internal or external) that a person judges as being above their resources ${ }^{(44)}$. It is understood, therefore, that the means an individual uses to cope may change over time, according to the features of the stressor and contextual factors ${ }^{(45)}$.

Faced with a stressful situation, individuals develop different ways of coping, which are related to personal factors, situational demands and available resources; and aim to restore the balance of the organism to the reactions triggered by the stressor. The types of coping strategies used in specific situations are in accordance with an individual's personality, past experience, and the characteristics of the situation ${ }^{(46-47)}$.

According to the Transactional Model of Stress, the person-environment relationship is a dynamic interaction between a person and his or her environment and stress results from a perceived imbalance between an individual's resources and the demands placed on them. The Model also assumes that the individual brings to every event or situation beliefs, values, attitudes, and behaviours developed over a lifetime under the influence of genetic, personal, social, and environmental factors. These contribute to a worldview and shape the meaning, value, and significance ascribed to a particular situation or event and helps to explain why two individuals may perceive and react differently to the same circumstances ${ }^{(48)}$.

The coping processes constitute a mobilization of cognitive and behavioral efforts to manage (reduce or tolerate) the internal or external demands that arise from the interaction with the environment ${ }^{(48)}$. These coping efforts may be either problem-focused or emotion-focused. The way a person perceives a stressful situation (i.e., cognitive appraisal) influences how they will attempt to cope ${ }^{(49-50)}$.

Problem-focused coping focuses on changing the environment to eliminate or modify the stressful situation. In other words, the person seeks to understand the stressor and tries to modify it. Emotionfocused coping is aimed at alleviating the emotional distress experienced by the person. That is, the person tries to mitigate the suffering related to the stimulus( ${ }^{(51)}$. Emotion-focused coping can be considered a way of avoiding direct confrontation with the stressor and referred to as avoidant coping.

Studies included in this review focused on childhood experiences, which would be considered as traumatic. This finding is aligned with the results of other studies, including a study ${ }^{(52)}$ with families and children about the use of substances that connect physical, emotional and sexual abuse to a sense of degradation, humiliation and drug use. Also, individuals who suffered multiple maltreatments had low self-esteem and were involved in more risk behaviours, including increased use of alcohol and other drugs ${ }^{(53)}$.

In an attempt to avoid the negative feelings, participants used the addiction behaviours as a way of trying to escape painful memories or limit stressful situations, what is referred to as avoidant coping. There's a relationship between early life stress, educational level, and the use of avoidant coping in the misuse of substances and mental disorders in women ${ }^{(54)}$.

Avoidant (emotion focused) coping does not solve problems caused by stressors. It is a way around the problem, which can cause further consequences such as addiction, crime and violence, for example. Addiction is just one of the many problems faced by these individuals, and the interplay of addiction, negative relationships, and violence can contribute to the misuse of substances as a means of escape from adverse circumstances.

Considering the linkage among addiction, crime and domestic violence, a person who developed addiction behaviour as a coping strategy can create a cycle of early-life stress across the generations. Two major themes were apparent in terms of avoidance coping: 1) repeating dysfunctional patterns from the family of origin, and 2) pain caused by traumatic memories.

\section{Repeating Dysfunctional Patterns from the Family of Origin}

Most often, children in the reviewed studies accepted the abuse from their relatives and did not try to retaliate, even if they were physically capable of doing so. This was way out of the realm of experiencing love 
and respect. In fact, these children accepted that being abused was a part of being a child. In justifying their punishments, they came to define parental assault as culturally normative as revealed in some of the reviewed $\operatorname{articles}^{(37-38,41,43,55)}$.

Often, there is no self-reflection about this behaviour, which leads to a repetition of the dysfunctional pattern of abuse and addiction within the family environment. As the person has no knowledge of how to cope otherwise with the traumatic events he/she is experiencing, they continue to adopt and repeat the same behaviours learned within the family environment.

It was recognized that some participants were using the same learned behaviour as a method of discipline that their parents had used. Unfortunately, it is noted that their development and ability to process family interactions are likely to be impaired with predictable outcomes; and that such situations have potential for perpetuating the patterns of vulnerability and risk for these adults. This creates a vicious cycle of abuse and addictive behaviour.

\section{Forgetting Pain Caused by Traumatic Memories}

The addiction behaviours are an understandable attempt to decrease the emotional and mental pain caused by such traumatic and violent experiences. The individuals disclosed experiences of abuse, incest, rape and many other horrors that lead to drug and alcohol use, in order to extinguish pain as revealed in many of the reviewed(32-36,39-40,55).

The participants in the reviewed studies used an array of different drugs to find balance in a life of pain. A lack of self-esteem, the tendency toward depression, and the feelings of shame and inadequacy set the stage for addiction behaviour. Indeed, it was a form of selfmedication, because with these substances can come some temporary relief to the pain of recalling severe and traumatic memories.

As the traumatic past memories cause pain, the use of substances can be seen as a way to alleviate the suffering. The substance abuse is viewed as a means to feel more comfortable at facing, emotionally, the deleterious consequences of child abuse. It is a nonassertive way of coping with the situation in the same way that the analgesic does not cure, only brings temporary but immediate relief. This does not solve the trauma, quite the opposite, as the misuse of substances can bring forth more complex problems that result from addiction.

However, the addiction behaviour is often perceived as a unique recourse for handling the trauma. In other words, this is an opportunity for health professionals, especially those who engage in community work, to become aware of childhood trauma indications and to offer new resources to this at risk population.

\section{Addiction, Violence, and Crime}

One of the major findings from the present study is that violence was commonplace in the household. Prior examination of literature reveals that household violence is part of a complex of sub-cultural norms that can involve drug use and sexual exploitation. Such a scenario can be seen in other qualitative studies, revealing the problem of violence in the context of misuse of substances ${ }^{(55-56)}$.

The result of substance abuse together with the social context in which people find themselves, as well as the absence of family or support systems, may set up a dynamic between parent and child which can increase risks of early-life stress. This cycle of addiction-violence-addiction is perpetuated, passing from parents to children, being renewed, constantly. The number of children affected by parental substance misuse, globally, is a social issue requiring action at many organizational levels.

In addition to domestic violence, addiction may be seen as a catalyst for crime, or a way to sustain an addiction behaviour or addictive life that has been influenced by traumatic events experienced since childhood within the family environment. Different scenarios are seen, whereby people who grew up in the middle of the violence use this to maintain the addiction. Sometimes the violence is a result of addiction, and viewed as a complication. Other times, the drug trade keeps the circle of violence, crime and addiction behaviour going. As such, family structure and parenting dynamics emerged as important themes by which to understand these pathways to addiction in adulthood. We can see, within this review, which individuals were from disruptive homes. Their stories indicated that childhood experiences can be traumatic and may continue to affect their life course, including the presence of addictive behaviours.

The reason that addiction leads to crime is varied, sometimes family addiction can lead to difficulty paying bills as parents use all their resources to support their habits, and resort to crime along the way. Addiction led to a lot of difficulty holding down jobs, and with unemployment came the start up of criminal activity to support drug habits.

In other words, it is known that, sometimes, criminal activity, early-life stress and addiction behaviour are closely related. Thus, preventive actions targeted at the identification of child abuse, can prevent not only the harmful consequences of addiction, but also prevent 
lower levels of violence related to this phenomenon. In other words, if it is possible to act preventively in child abuse cases, it is possible to prevent addiction behaviours, domestic violence and criminal activities.

In providing assistance to individuals exhibiting addiction behaviour, it is crucial to consider the presence of early stressors as a feature of great importance in the life history of the person. Identifying and accepting such stressful experiences in childhood can help the health professional and client better understand the meaning of these behaviours; thus enabling a redefinition or reframing of trauma experiences and a search for coping strategies that are more constructive in nature.

\section{Relevance for clinical practice}

The growth of children encompasses physical, emotional, cognitive and psychological existence. Parents can support this growth in many ways, sometimes positively, other times not. They can contribute positively to the child's sense of security, ability to form healthy relationships, and ability to become a productive adult(57). When there is a lack of this support, the child needs quality care and sustained attention in order to avoid deleterious consequences in the future.

Nurses working in community and/or pediatric areas are in an ideal position to identify children affected by child maltreatment and to assist them in finding the help they need, including addiction prevention or treatment if the child or teen is already exhibiting addiction behaviour to cope with their adversities. Consequently, nurses are able to make a difference in the approach to challenges like early-life stress and addiction behaviour through a comprehensive or holistic nursing lens that considers the social, environmental, personal, and health dimensions of each person's situation.

In addition, nurses can provide advanced mental health care in terms of family needs related to physical and psychological health, healing, and wellbeing based on an assessment process and action plan derived from knowledge of the client's life that includes stories of early-life stress and addiction.

Community resources must be made available to those individuals having experienced adverse events such as child abuse. Nurses working throughout the healthcare system have the capacity to connect those in need and their families with appropriate resources, as well as help them navigate a system that leads to obtaining the care they require. Lastly, this study opens a window for further research that seeks a deeper understanding of the connections between early life adverse experiences, human addictive behaviour, and trauma-informed care that could be harnessed through the professional discipline of nursing, as well as through interdisciplinary work with the health sciences.

\section{Limitations}

One of the limitations of this study is the lack of access to transcripts of the included material. Due to it being a metasynthesis, access to the transcripts of the participants could bring greater depth to the discussion, which limits the interpretation of synthesized information. In spite of these limitations, the metasynthesis revealed some promising results that can inform and guide effective health promotion and disease prevention actions in nursing practice.

\section{Conclusions}

The metasynthesis review provides an understanding of the link between the experience of addiction and early-life stress. It can be inferred that addiction may be viewed as a way to deal with adversity in childhood and that there is an interrelationship between addiction, domestic violence and crime. The results are useful to clinicians, nurses and health professionals seeking a deeper understanding of individual perspectives related to adverse life events. This knowledge can be incorporated into practice, leading further to new links between research and treatment.

This metasynthesis highlights several areas for future research. There is a clear indication that increasing the focus on understanding addiction behaviours in persons who have experienced early-life stress, in the context of their perceptions and understandings, would be valuable. At the same time, it is imperative that concerted efforts be made to improve the quality of life of this population through health promotion, disease prevention, and intervention strategies specific to mental health.

\section{Acknowledgments}

To Luis Carlos Lopes Júnior for his hard work and assistance during search strategies on electronic databases and to Faculty of Nursing of University de Alberta (Canada) for support.

\section{References}

1. National Scientific Council on the Developing Child. The science of neglect: The persistent absence of responsive care disrupts the developing brain: Working paper 12 [Internet]. 2012. [Cited 2015 Oct 15]. Available from: http://www.developingchild.harvard.edu 
2. Martins CM, Tofoli SMC, Von Werne Baes C, Juruena M. Analysis of the occurrence of early life stress in adult psychiatric patients: A systematic review. Psychol Neurosci. 2011;4(2):219. doi: http://dx.doi. org/10.3922/j.psns.2011.2.007.

3. Williams LCA. Abuso sexual infantil. In Guilhardi, HJ, Madi MBB, Queiroz PP, Scoz MC, editors. Sobre comportamento e cognição: Contribuições para a construção da teoria do comportamento. São Paulo: ESETec; 2002.

4. World Health Organization [WHO]. Child maltreatment: Factsheet No. 150 [Internet]. 2014. [Cited 2015 Oct 15]. Available from: http://www.who.int/violence_injury_ prevention/violence/child/en/

5. Bernstein DP, Stein JA, Newcomb MD, Walker E, Pogge D, Ahluvalia T, et al. Development and validation of a brief screening version of the Childhood Trauma Questionnaire. Child Abuse Negl. 2003 Feb 28;27(2):169-90. doi: http://dx.doi.org/10.1016/ S0145-2134(02)00541-0

6. Afifi TO, Mota NP, Dasiewicz P, MacMillan HL, Sareen J. Physical punishment and mental disorders: results from a nationally representative US sample. Pediatrics. 2012 Aug 1;130(2):184-92. doi: 10.1542/peds.2011-2947

7. Anda RF, Felitti VJ, Bremner JD, Walker JD, Whitfield $\mathrm{CH}$, Perry $\mathrm{BD}$, et al. The enduring effects of abuse and related adverse experiences in childhood. Eur Arch Psychiatry Clin Neurosci. 2006 Apr 1;256(3):174-86. doi: 10.1007/s00406-005-0624-4.

8. Rao S, Lux AL. The epidemiology of child maltreatment. Pediatr Child Health. 2012 Nov 30;22(11):459-64. doi: http://dx.doi.org/10.1016/j.paed.2012.09.002.

9. Gilbert R, Widom CS, Browne K, Fergusson D,

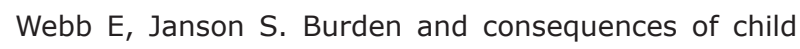
maltreatment in high-income countries. Lancet. 2009 Jan 9;373(9657):68-81. doi: http://dx.doi.org/10.1016/ S0140-6736(08)61706-7.

10. Norman RE, Byambaa M, De R, Butchart A, Scott J, Vos T. The long-term health consequences of child physical abuse, emotional abuse, and neglect: a systematic review and meta-analysis. PLoS Med. 2012 Nov 27;9(11):e1001349. doi: http://dx.doi. org/10.1371/journal.pmed.1001349.

11. Stoltenborgh M, Bakermans-Kranenburg MJ, van IJzendoorn $\mathrm{MH}$. The neglect of child neglect: a metaanalytic review of the prevalence of neglect. Soc Psychiatry Psychiatr Epidemiol. 2013 Mar 1;48(3):34555. doi: 10.1007/s00127-012-0549-y.

12. Stoltenborgh $M$, van IJzendoorn $M H$, Euser EM, Bakermans-Kranenburg MJ. A global perspective on child sexual abuse: meta-analysis of prevalence around the world. Child Maltreatment. 2011 May 1;16(2):79101. doi: 10.1177/1077559511403920.
13. Grassi-Oliveira R, Stein LM, Pezzi JC. Tradução e validação de conteúdo da versão em português do Childhood Trauma Questionnaire. Rev Saúde Pública. 2006 Apr;40(2):249-55. doi: http://dx.doi.org/10.1590/ S0034-89102006000200010.

14. Felitti VJ, Anda RF, Nordenberg D, Williamson DF, Spitz AM, Edwards V, et al. Relationship of childhood abuse and household dysfunction to many of the leading causes of death in adults: The Adverse Childhood Experiences (ACE) Study. Am J Prev Med. 1998 May 31;14(4):245-58. doi: http://dx.doi.org/10.1016/ S0749-3797(98)00017-8.

15. Wonderlich SA, Rosenfeldt S, Crosby RD, Mitchell JE, Engel SG, Smyth J, et al. The effects of childhood trauma on daily mood lability and comorbid psychopathology in bulimia nervosa. J Trauma Stress. 2007 Feb 1;20(1):7787. doi: https://dx.doi.org/10.1002/jts.20184.

16. Mello MF, Faria AA, Mello AF, Carpenter LL, Tyrka AR, Price LH. Maus-tratos na infância e psicopatologia no adulto: caminhos para a disfunção do eixo hipotálamopituitária-adrenal. Rev Bras Psiquiatr. 2009 Oct; 31(Supp.2):S41-48 doi: http://dx.doi.org/10.1590/ S1516-44462009000600002.

17. Enoch MA. The influence of gene-environment interactions on the development of alcoholism and drug dependence. Curr Psychiatry Rep. 2012 Apr 1;14(2):150-8. doi: 10.1007/s11920-011-0252-9.

18. Sandelowski M, Barroso M. Handbook for synthesizing qualitative research. New York: Springer; 2007.

19. Sandelowski M, Docherty S, Emden C. Focus on qualitative methods Qualitative metasynthesis: issues and techniques. Res Nurs Health. 1997 Aug;20:365-72. 20. Walsh D, Downe S. Meta-synthesis method for qualitative research: a literature review. J Adv Nurs. 2005 Apr 1;50(2):204-11. doi: https://dx.doi. org/10.1111/j.1365-2648.2005.03380.x.

21. Zimmer L. Qualitative meta-synthesis: a question of dialoguing with texts. J Adv Nurs. 2006 Feb 1;53(3):311-8. doi: https://dx.doi.org/10.1111/j.13652648.2006.03721.x.

22. Finfgeld-Connett D. Generalizability and transferability of meta-synthesis research findings. J Adv Nurs. 2010 Feb 1;66(2):246-54. doi: 10.1111/j.13652648.2009.05250.x.

23. Grant MJ, Booth A. A typology of reviews: an analysis of 14 review types and associated methodologies. Health Info Libr J. 2009 Jun 1;26(2):91-108. doi: 10.1111/j.1471-1842.2009.00848.x.

24. Joanna Briggs Institute. Joanna Briggs Institute reviewers' manual: 2008 edition. Adelaide; 2008.

25. Critical Appraisal Skills Programme [CASP]. CASP Qualitative Research checklist [Internet]. 2013. [Cited 2015 Oct 15] Oxford, UK. Available from: http://media. 
wix.com/ugd/dded87_29c5b002d99342f788c6ac670e4 9f274.pdf

26. Public Health Resource Unit. The Critical Skills Appraisal Programme: Making sense of evidence [Internet]. 2006. [Cited 2015 Oct 20]. Available from: http://www.casp-uk.net/

27. Ursi ES, Gavão CM. Perioperative prevention of skin injury: an integrative literature review. Rev. LatinoAm. Enfermagem. 2006 Feb;14(1):124-31. doi: http:// dx.doi.org/10.1590/S0104-11692006000100017

28. Vasconcelos CT, Damasceno MM, Lima FE, Pinheiro AK. Integrative review of the nursing interventions used for the early detection of cervical uterine cancer. Rev. Latino-Am. Enfermagem. 2011 Apr;19(2):437-44. doi: http://dx.doi.org/10.1590/S0104-11692011000200028 29. Vilar AM, Andrade M, Alves MR. Discharge of children with stomas: integrative literature review. Referência. 2013 Jul:145-52. doi: http://dx.doi.org/10.12707/ RIII12113.

30. Patton MQ. Qualitative research and evaluation methods. 4rd ed. Thousand Oaks, CA: Sage Publications; 2014.

31. Whittemore $R$, Knafl $K$. The integrative review: updated methodology. J Adv Nurs. 2005 Dec 1;52(5):546-53. doi: https://dx.doi.org/10.1111/ j.1365-2648.2005.03621.x.

32. Bowles MA, DeHart D, Webb JR. Family influences on female offenders' substance use: The role of adverse childhood events among incarcerated women. J Fam Viol. 2012 Oct 1;27(7):681-6. doi:10.1007/s10896012-9450-4.

33. Davis RE, Mill JE, Roper JM. Trauma and addiction experiences of African American women. West J Nurs Res. 1997 Aug 1;19(4):442-65.

34. Johnson HD, Young DS. Addiction, abuse, and family relationships: Childhood experiences of five incarcerated African American women. J Ethn Subst Abuse. 2002 Sep 1;1(4):29-47. doi: http://dx.doi.org/10.1300/ J233v01n04_02.

35. Mirlashari J, Demirkol A, Salsali M, Rafiey $H$, Jahanbani J. Early childhood experiences, parenting and the process of drug dependency among young people in Tehran, Iran. Drug Alcohol Rev. 2012 Jun 1;31(4):4618. doi: 10.1111/j.1465-3362.2011.00384.x.

36. O'Brien AM, Brecht ML, Casey C. Narratives of methamphetamine abuse: A qualitative exploration of social, psychological, and emotional experiences. J Soc Work Pract Addict. 2008 Jul 23;8(3):343-66. doi: http:// dx.doi.org/10.1080/15332560802224469.

37. Bittar DB, Nakano AM. Domestic violence: life history analysis of aggressive mothers users of alcohol and drugs in the context of their original families. Texto
Contexto Enferm. 2011 Mar;20(1):17-24. doi: http:// dx.doi.org/10.1590/S0104-07072011000100002.

38. Bittar DB, Nakano AM, Silva MA, Roque EM. Violência intrafamiliar contra crianças e adolescentes na percepção de mães agressoras. Rev Eletr Enferm. [Internet]. 2012 Dec [cited 2015 Oct 20]. 31;14(4):771-8. Available from: https://www.fen.ufg.br/fen_revista/v14/n4/ pdf/v14n4a04.pdf doi: http://dx.doi.org/10.5216/ree. v14i4.15739.

39. Davison J. Alcohol misuse: contributor to and consequence of violence against women. Divers Equal Health Care. 2007;4:137-48.

40. Hänninen V, Koski $\square$ Jannes A. Narratives of recovery from addictive behaviours. Addiction. 1999 Dec 1;94(12):1837-48.

41. Valtonen K, Padmore JC, Sogren M, Rock L. Lived experiences of vulnerability in the childhood of persons recovering from substance abuse. J Soc Work. 2009 Jan 1;9(1):39-60. doi: 10.1177/1468017308098427.

42. Dunlap E, Golub A, Johnson BD, Benoit E. Normalization of violence: experiences of childhood abuse by inner-city crack users. J Ethn Subst Abuse. 2009 Feb 27;8(1):15-34. doi: 10.1080/15332640802683359. 43. Coyer SM. Women in recovery discuss parenting while addicted to cocaine. MCN: The Am J Matern Child Nurs. 2003 Jan 1;28(1):45-9.

44. Carnier LE, Padovani FH, Perosa GB, Rodrigues OM. Estratégias de enfrentamento em crianças em situação pré-cirúrgica: relação com idade, sexo, experiência com cirurgia e estresse. Estud Psicol (Campinas). 2015 Jun 1:319-30. doi: http://dx.doi.org/10.1590/0103166X2015000200015

45. Mitchell RE, Cronkite RC, Moos RH. Stress, coping, and depression among married couples. J Abnorm Psychol. 1983 Nov;92(4):433.

46. Laal M, Aliramaie N. Nursing and coping with stress. Int J Collab Res Intern Med Public Health. 2010 May;2(5):168-81.

47. Teixeira CA, Reisdorfer E, da Silva Gherardi-Donato EC. Occupational stress and coping: reflection on the concepts and practice of hospital nursing. Rev enferm UFPE online [Internet]. 2014 Apr 6 [cited 2015 Oct 16]; 8(7):2528-32. Available from: http://www.revista. ufpe.br/revistaenfermagem/index.php/revista/article/ viewArticle/6279 doi: 10.5205/reuol.5927-50900-1SM.0807suppl201443.

48. Lazarus RS, Folkman S. Stress, appraisal and coping. New York: Springe Publishing Company; 1984.

49. Folkman S, Lazarus RS. An analysis of coping in a middle-aged community sample. J Health Soc Behav. 1980 Sep 1:219-39.

50. Folkman S, Lazarus RS. If it changes it must be a process: study of emotion and coping during three 
stages of a college examination. J Pers Soc Psychol. 1985 Jan;48(1):150.

51. Seidl EM, Tróccoli BT, Zannon CM. Análise fatorial de uma medida de estratégias de enfrentamento. Psicol Teor Pesqui. 2001 Sep;17(3):225-34. doi: http://dx.doi. org/10.1590/S0102-37722001000300004.

52. Magor-Blatch L. Child deaths and statutory services: Families and Substance Use: Building a Resource for Recovery. Communities, Children and Families Australia. $2007 \mathrm{Dec} ; 3(1): 33$.

53. Arata CM, Langhinrichsen-Rohling J, Bowers D, O'Farrill-Swails L. Single versus multi-type maltreatment: An examination of the long-term effects of child abuse. J Aggress Maltreat Trauma. 2005 Aug 25;11(4):29-52. doi: http://dx.doi.org/10.1300/J146v11n04_02.

54. Min M, Farkas K, Minnes S, Singer LT. Impact of childhood abuse and neglect on substance abuse and psychological distress in adulthood. J Trauma Stress. 2007 Oct 1;20(5):833-44. doi: https://dx.doi. org/10.1002/jts. 20250.

55. Dunlap E, Golub A, Johnson BD. The severelydistressed African American family in the crack era: Empowerment is not enough. J Sociol Soc Welf. 2006;33(1):115.

56. Dunlap E, Golub A, Johnson BD. Transient malefemale relationships and the violence they bring to girls in the inner city. J Afr Am Stud. (New Brunsw) 2003 Sep $1 ; 7(2): 19-36$

57. Werner EE, Smith RJ. Overcoming the odds: High risk children from birth to adulthood. New York: Cornell University; 1992. Creative Commons (CC BY).

This license lets others distribute, remix, tweak, and build upon your work, even commercially, as long as they credit you for the original creation. This is the most accommodating of licenses offered. Recommended for maximum dissemination and use of licensed materials. 